\title{
HISTORICAL DIALOGUES, COLLECTIVE MEMORY WORK, AND THE (DIS)CONTINUATION OF CONFLICTS
}

\author{
Sara Dybris McQuaid \\ Aarhus University \\ engsdm@cc.au.dk
}

Henrik Sonne Petersen

Danmission

henriksonnp@gmail.com

Johnston Price

Five Decades Project at Forthspring

\begin{abstract}
This article is at once about historical dialogues and itself a dialogue: In an effort to discuss historical dialogues in the intersection between the academic field of memory studies and the practical field of peace-building, the article offers a semi-structured conversation between an academic and two practitioners. It is on the one hand an exploratory dialogue aimed at identifying and observing potential entry points for analysis and practice in conflict transformations, whilst on the other a discussion of how historical dialogues themselves are framed as open and exploratory or principled and tied to preconditions. The first conversation is between an academic and a practitioner engaged directly in historical dialogues through a storytelling project in Northern Ireland. They bring together theoretical, practical, and methodological considerations of moving between levels of memory as well as understanding historical dialogues at once as processes and products. The second conversation is with a practitioner who works with peacebuilding and dialogue, but not yet from an explicit entry point of historical dialogue. This conversation explores the role of religion and religious practice as powerful institutions and instruments in bridging individual and collective memory, as well as challenging community cohesion. As such, the article deals with historical dialogues that bring the past into the present, i.e. storytelling projects (the first conversation), or upon which memory work may be brought to bear, i.e. reading preventive dialogues also as historical dialogues (second conversation). The chapter concludes with a brief discussion of how memory work can become part of peacebuilding practices.
\end{abstract}




\section{Keywords}

conflict; East Africa; memory; Northern Ireland; peace-building; prevention; reconciliation

\section{About the Authors}

Sara Dybris McQuaid (PhD) is Director for the Centre for Irish Studies (2012-), an Associate Professor in British and Irish History, Society and Culture at Aarhus University and a core research partner in Centre for Resolution of International Conflicts at Copenhagen University. Her research pivots around how collectives remember, forget and archive their past, particularly as part of conflict and peacebuilding processes. She has worked extensively on Northern Ireland and is particularly interested in 'multi-level memory governance', where transnational, national and local actors, processes, products and practices give shape to each other. She teaches in the English Degree Programme and the MA in intercultural Studies.

Henrik Sonne Petersen (PhD) has a background in ethics and philosophy of religion, and following teaching assignments in Denmark and Ethiopia he worked with Danmission for 12 years heading, among other things, the engagement with interreligious relations. As part of the interreligious and peace-oriented work he made studies in the relation between religion and security in East Africa, aiming to complement a conventional political perspective with an ethical angle.

Following his studies at the University of Ulster and Warwick, Johnston Price was awarded his $\mathrm{PhD}$, titled Marxism and Ethics, by the University of Sussex in 1987. He went on to a career with the Ulster People's College in Belfast, an institute aiming "to involve people in tackling social and economic problems and in overcoming cultural and political divisions." Over his twenty years there he became the director of the college. Following this he joined Forthspring, an interface project promoting a greater sense of shared identities within the two communities. This developed his interest in oral history, which he channeled into the Five Decades Project. 


\section{INTRODUCTION}

This article is about historical dialogues and is itself conducted as a dialogue. It aims to discuss the pitfalls and potentialities of doing memory work and conducting historical dialogues in conflict transformation while, at the same time, exploring the relationship between the academic field of memory studies and the practical field of peacebuilding. As such, the article offers a semi-structured conversation between an academic and two practitioners ${ }^{1}$ with a shared interest in allowing theoretical frameworks and specific practices and experiences to give firmer shape and support to each other. It is on the one hand an exploratory dialogue aimed at identifying and observing potential entry points for analysis and practice, while on the other a discussion of the extent to which historical dialogues themselves are open and exploratory or principled and tied to preconditions. Central questions revolve around what kind of frameworks enable or force dialogues to begin and, as historical narratives change, what modes of memories are involved in that process.

After a brief introduction to the heightened importance of historical dialogues and forms of memory work for academics and practitioners alike, the conversations unfold as written dialogues with four to five main points. ${ }^{2}$ Based on these, the practitioners' cases and experiences are foregrounded throughout and used as springboards to probe how insights from memory and conflict studies can be engaged in particular processes. In the same vein, the cases raised by the practitioners test the boundaries and limitations of the academic field and point toward future research agendas. The first conversation takes place between an academic and a practitioner, both of whom have directly engaged in historical dialogue and memory work through the compilation of a storytelling project in Northern Ireland. This conversation will bring together academic, practical, and methodological considerations of moving between levels of individual and collective memory. This will also entail understanding memory work (in this case storytelling practices) at once as processes (of catharsis, reconciliation) and products (archived narratives for future use). The second conversation puts forward the dilemmas raised in the first conversation to a practitioner who works in peacebuilding, but not explicitly on memory. In this conversation we explore the extent to which the memory framework is useful primarily as an analytical tool (to understand conflict) or whether it has leverage as an operational tool as well. This conversation considers the role of faith societies and religious practice as powerful institutions and instruments in bridging individual and collective memory, as well as challenging community cohesion. While memorialization may be understood in a number of ways, this article focuses on activities that bring the past into the present through storytelling (i.e. the first conversation), or through a consideration of preventive dialogue as a form of historical dialogue (i.e. the second conversation). This article concludes with a brief discussion of how memory work can become a 
more integral part of peacebuilding practices in different contexts, highlighting particularly the importance of agonistic and reflexive memory work.

\section{BRINGING HISTORICAL DIALOGUES AND MEMORY WORK ONTO THE PEACEBUILDING AGENDA}

Memory conflicts can be construed as clashing or competing interpretations of history, as collective actors struggle to establish exclusive hegemonic narratives. This can happen during escalations (as parties drag former victories, injustices, and skeletons out of the historical closet), during conflict itself (as ongoing violent incidents are read into existing antagonistic narratives), and after violent conflict has ended (as contested narratives in protracted conflicts develop dynamics of their own, which at once feed off each other and can exist without recognition

of each other). Contestations are often more than discursive, as related practices of commemoration can lead not just to cultural violence (Galtung) but also to physical clashes in and over public space (McDowell and Braniff). By the same token, memory conflicts can also take the form of silences and absences as some memory discourses find public expression and recognition and others are subject to erasure, structural amnesia (see Connerton), and "disremembering" (Beiner). Conflicts may arise from such disconnects between official histories and vernacular memories in which marginalization can lead to radicalization. Memory work, then, engages directly in the articulation of contested memories and the transformation of their destructive modes.

Different forms of memorialization are becoming increasingly important tools of conflict resolution and transitional justice, as the ways in which conflicts are remembered and memorialized may speak directly to the ways in which they can be transformed. Crucially, this work also happens before violence ends and should not just be conceived as a "post-conflict" endeavor. However, as Barsalou and Baxter have argued, international and local peace-building actors are often drawn inadvertently into "memory conflicts," but rarely feel comfortable engaging with them as such (see also Barsalou). This is not least because experiences and narratives of violent pasts are seen to entrench mutually exclusive (even mutually destructive) identities in group conflicts and thus mainly hold potential for protracting conflict and division, as groups remember and forget against each other. In such contexts, dwelling on the past is neither considered productive nor constructive and so peace building, particularly by third parties, often focuses on forward-looking and pragmatic goals, in which historical conflict may be bracketed. 
At the same time, conflict resolution scholars and practitioners have long considered reconciliation of narratives and histories as an important part of postviolencepeacebuildingin protracted conflicts (Ramsbotham, Miall, and Woodhouse). Dealing with the past, as such, is not just about recognizing injustices done to individuals, communities, and societies in conflict, but also about giving voice to diverse experiences of conflict. Increasingly, this is done through various forms of remembrance, where international agenda- (and norm)-setting organizations pay much more attention to articulations of the past in conflict resolution. For example, in 2014, a session of the United Nations Human Rights Council (UNHRC) was devoted to a panel discussion on history-teaching and memorialization processes with a view to, inter alia, contributing to the sharing of good practices in this area. In her opening statement, the Deputy High Commissioner for Human Rights stated that "Reconciliation processes clearly needed to weave new and inclusive historical narratives." She championed a "multi-perspective" approach to history and commemorations, which might at once offer recognition of different perspectives, promote civic engagement, and promote critical thinking (Human Rights Council).

In this vein, dealing with the past is seen to hold progressive potential in terms of redrawing mental and material maps of conflict by encouraging new and more reflexive dynamics of memory and history. However, in order to harness this potential we need specific understandings as well as dynamic ideas about what kind of a field or process collective memory is and how "memory conflicts" may play out in cycles of violence and peace. We also need to understand how such dynamics are and can be engaged "on the ground" in different contexts in which continued violence may or may not be a dynamic factor. Historical dialogue, by engaging with the memory of past violence, creates a context, as the following conversations illustrate, in which historical narrative itself can be considered a component of the conflict transformation process.

\section{CONVERSATION ON THE INTERFACE OF A PROTRACTED PEACE PROCESS}

Johnston Price is the director of the 5 Decades Project and works for Forthspring, an intercommunity group situated in Belfast, Northern Ireland. To situate the project in relation to the conflict in and over Northern Ireland, a brief overview of Northern Ireland's recent past is useful to consider.

Between 1968 and 1998, Northern Ireland was embroiled in a violent conflict in which over 3,500 people were killed and 42,216 were injured (Elliot and Flackes 681687). It is often considered an ethno-national conflict wherein religious background 
(either Protestant or Catholic) largely aligns with the exclusive national political ideologies of unionism and nationalism (to see Northern Ireland as rightfully part of the United Kingdom or the island of Ireland). These religious differences and constitutional contestations underlaid the direct violence which broke out in the late 1960 s when the Northern Ireland Civil Rights Association mobilized to demand an end to discrimination against the Catholic population by the majority Protestant government. Increasingly violent clashes between the state and civil rights activists and between the two sections of society saw the British Army dispatched to Northern Ireland in 1969. In 1969, makeshift barricades were made into the first so-called "peace walls" to separate the Protestant and the Catholic communities in Belfast. In the ensuing thirty years of conflict, which saw the British government suspend the Northern Ireland Parliament (1972) and paramilitary groups engage the British Army and each other in sectarian warfare, Northern Irish society became increasingly segregated in psychological, social, cultural and political terms. After many failed attempts, a political peace agreement was reached in 1998. The agreement saw a historic political compromise between unionists and nationalists. It also ensured continued paramilitary ceasefires, release of prisoners, British demilitarization, and police reform. However, despite the peace agreement, societal segregation persists in what is often termed a "cold peace" twenty years on. At the same time, how to interpret the conflict remains contested, and nationalist and unionist politicians have yet to implement a policy on how to deal with the past in legal, social, economic, historical, and reconciliatory terms. This resistance to dealing with the past means that ongoing historical dialogues take place largely without political leadership and in the absence of firm policy contexts-restricting how and what types of things can be articulated and addressed. However, at the same time, the civil society gives much focus "reconciling communities" in Northern Ireland to transform conflictual relationships more fully. This focus has been intensified through large scale European Union (EU) peace funding for reconciliation oriented toward acknowledging and dealing with the past in Northern Ireland (Special EU Programmes Body). Substantial portions of this funding have gone to various "storytelling projects."

Storytelling, as defined by the NGO Healing Through Remembering, ${ }^{3}$ is "[a] project or process which allows reflection, expression, listening, and possible collection of personal, communal and institutional stories related to the conflict in and over Northern Ireland." Over 70 storytelling projects matching this definition have been launched and recorded (Hamber and Kelly). Forthspring's 5 Decades Project is one of these initiatives and here we consider "storytelling" a form of historical dialogue.

Originally a Methodist church, the community-based organization Forthspring has worked since 1997 to build relationships between the local neighboring 
Protestant and Catholic communities. Forthspring is housed between the predominantly Protestant Shankill Road and the predominantly Catholic Falls Road and, as such, is literally part of the so-called "peace-line" constructed since 1969. Operating from this "interface," the community group is well placed to both breach and bridge social and physical boundaries. Under the Special EU Programmes Body/Peace III referred to above, Forthspring applied for funding for the dual purposes of gathering the stories of people who lived through the conflict on either side of this interface from the 1960 s onwards and to create a space where such stories could be shared, if not agreed on. Assuming that a key driver of continued animosities was an exclusive version of conflict and aggression, the rationale of the storytelling project was to "set out with the objective of acting as a conduit for the narration and hearing of stories," concluding "that the humanity can be found in the detail of individual stories" (Forthspring).

\section{On Memory and Historical Dialogues as both Processes and Products}

Sara McQuaid (SM): Let me first thank you for agreeing to have this exchange on memory as a motor in conflict and peacebuilding. Since I first encountered the 5 Decades Project in 2013, I have been impressed with the work you are doing and intrigued by the challenges it presents. From discussions dating back to 2014, it has been clear to me that many of the storytelling projects taking place in Northern Ireland were at once processes and products. That is, on the one hand, they are processes of sharing stories and memories with others, where telling and listening are acts of generosity that sometimes forge new links between the people who engage in these activities. At the same time, the stories become (are even made into) a kind of product, that is, when they are stored for future (or indeed contemporary) retrieval in online archives, or published in book form. ${ }^{4}$ Where the first process can perhaps be said to be about restoring dignity for the individual and relationships between individuals, the secondary product is about contributing (re)sources for a fuller account of conflict for other people, including historians like myself. So my first question would be: how present were these two, at once similar and different concerns, in shaping the 5 Decades Project?

Johnston Price (JP): As you know the 5 Decades Project, as constructed by Forthspring, is about reconciliation - a shared, but not necessarily agreed, account of the conflict. We began by searching out the stories of people who lived along the Shankill/Falls interface in Belfast and have moved over time to other areas of Northern Ireland. Yes, indeed, process and product were both present in the 
initial design of the project. It seems self-evident that the process through which stories were and are heard comes before the construction of product (notes, audio interviews, online material, exhibitions, publication, etc.) but only in the simplest of sense. However, from the start of the Project, I found that there was a constant back and forth between the two, a conscious and unconscious switching between both, each supporting the other. For example, short cryptic notes recorded during the process were later organized into themes and topics which were used to create cards that in turn were used as prompts in future storytelling sessions. My sense is that the Project is at its best when product feeds into the process and the two resonate, each enhancing the other. For example, the exhibition materials were used as the focus of sessions where groups of school children engaged in dialogue and discussion with participants in the Project.

The relationship between process and product is often important for participants, many of whom had a clear expectation that the process would lead to product. In early discussions about the Project, participants would often ask about the future of their stories. The Project's initial design acknowledged the ethical concerns around ,moving from process to product. Before starting it, Forthspring and myself were given initial support by Towards Understanding and Healing. ${ }^{5}$ In addition, excellent materials developed by Healing Through Remembering were used in this area and an advisory group was established before the Project began to help in this and other areas. The issue was brought in to sharp focus by the initial publicity around the Boston Tapes ${ }^{6}$ with that story coming in to the public realm at the time the 5 Decades Project was starting.

Both process and product were approached with an emphasis on the collective and the individual. This arose out of my background in adult education and community development and the strong sense I had that storytelling with a reconciliation focus had to put the collective at the center. Stories were told in groups with a focus on personal safety and collective sharing. Larger events further promoted the sharing and hearing of stories. When stories were collected, this was done on an individual basis, one-to-one interviews. But these interviews fed into the collective process through the exhibitions in Forthspring, Belfast City Hall and local libraries and the publication.

\section{On Individual and Collective Memory in Historical Dialogues}

SM: Your reflections on how the 5 Decades Project navigates the dynamics of processes and products, and how these levels are mutually constitutive are particularly significant. That is, how the process obviously helps give shape to 
individual memories, but also how these individual memories then become part of future plot points (or cards, as you say) to prompt other people's memories. In that respect, I would like to consider further your thinking in terms of collective and individual memory. In memory studies, there is a precarious consensus that collective memory can be conceptualized in two different ways. The individualist approach understands collective memory as an aggregate of individual memories, where the individual is the central focus of analysis. In those terms, only the individual remembers and collective memories are located in individual minds and relies on their individual ability for recall. The basic critique of this position is that it understates social and cultural contexts and equalizes or privileges different positions. On the other hand, collectivist approaches argue that collective memory is not reducible to the individual but is derived from the social frameworks that provide terms and definitions (including language, symbols, and systems) for cognitive processes and narratives (see Olick). Considering the fact that your project takes place on an interface and that people who participate are also in a sense representatives either side of religious and spatial terms, do you find that the boundaries between individual and collective memories often become blurred? Part of this question also concerns how "communal memories" impact individual memories and the modes of memory. Did people use antagonistic terms-that is, remembering against each other? Or did they use more agonistic terms-that is, allowing for differences and group identification whilst still exchanging and sharing? Or did you see completely new modes of memories? Finally, how did you see the modus operandi of the project contributing to the specific articulations of memory?

$J P$ : The overwhelming majority of the participants in the 5 Decades Project would clearly see themselves as members of either the Catholic or Protestant community, and their membership to those communities shapes their recollections, their memories, and the way they choose to present them. The participants' memories are more than individual memories, and there is a clear blurring between individual and collective memories. This is as much true of memories and stories that challenge the dominant discourse within the participants' communities as it is of memories and stories that re-inforce the dominant discourse. For example, there was an interesting story in which a participant who grew up in the Protestant community and ended up living in the Catholic community talks about having "a foot in both camps," of being in a kind of limbo. The story reflects that he was only able to successfully navigate this situation because he had a good sense of the dominant narratives in each community and was able to adjust in line with these. 
Your question about whether people remembered against each other is very interesting, as my sense of it was that this happened less than I would have expected. Politically, people of Northern Ireland often define themselves in opposition to others, but the stories tended to come from the participants' own experience with little or no antagonistic terms. On reflection, I think this arose from how people were encouraged to remember. They were asked to recall events in a group focusing on their lives and where and how they lived with a strong emphasis on individual decades and social, economic, and cultural history as well as politics: community life, church, entertainment, work, unemployment, music, and fashion. They were not asked to explain the conflict or discuss the rights and wrongs of it, though they were not prevented from doing so if they wished.

Without having explicit discussions or even thoughts about this in delivering the Project, I now think the important point is how we approached the goal of reconciliation. One approach to reconciliation is to see it as an individual experience, best achieved by individuals breaking from their traditional loyalties. Forthspring takes the approach that people enter our space and our projects as members of distinct communities and ethnic groups, and we not only accept that in most cases they will remain so but also believe that is how it should be. Reconciliation is a collective process between communities within which individuals play a part. So, 5 Decades consciously sets out to encourage a collective approach within communities and then to create engagements between communities.

My experience in Northern Ireland with regard to why the individualistic approach "equalizes or privileges different positions," is that some actors in peacebuilding wish to privilege stories of dissent that reject division. In steering away from that, 5 Decades took a very broad view of what the collective was. We consciously avoided words like "extremist" and sought to place the emphasis on listening in as value-free and agenda-free manner as possible apart from being very upfront about the goal of reconciliation and respect for yourself and others - a shared, but not agreed, account of the conflict. I confess to having thought little about memory during the project other than how memory can be evoked. This could be seen to be a very instrumental approach. Where it became a practical concern was with some of the residents of residential homes we worked in who had various forms of dementia. We used images and video, music and recordings and crucially built relationships between participants in small groups to encourage recall. In virtually all cases, we did not use the material due to the complexity of consent issues. The accuracy of stories, the accuracy of memory is very important to consider. At one level I checked detail in stories to quite an extreme level. I felt I had a duty to all participants that shared their stories that their stories should be included in a collection that was authentic - not necessarily in the sense of being supported by unquestionable evidence but at least in the sense of representative of 
the participants' beliefs and experiences and in that sense I hope that the Project is and has been true to the participants and the goals it has set itself.

\section{On the Impact of Funding}

SM: It seems your approach has allowed both for alternative individual narratives of conflict to organize and prompt memories according to the associative power of decades, and for continuing collective and communal identification rather than immediately attempting to transcend differences. This chimes very well with developments in memory studies which are becoming increasingly sensitive to the fact that mnemonic communities are not necessarily homogenous and nationally bounded, but vernacular and fractious as well, as part of wider transnational currents (Assman, "Transnational Memories"; De Cesari and Rigney; McQuaid and Gensburger). The divisive nature of memory is of course well recognized in conflict contexts, but your project also seems to offer new entry points for transnational anchoring as well. Using a decades approach, the "summer of 69 " can be about more than the outbreak of conflict and the arrival of British troops in Northern Ireland: it can also be about a far-reaching cultural revolution and the concomitant changes to everyday life, and perhaps most interestingly, about the dynamics between these local and transnational courses of events and experiences (McQuaid).

Your perspective on how to negotiate the implicit push to break away from group loyalties, and the extent to which dissent from the communal narratives may be privileged in peacebuilding efforts, is particularly intriguing. It brings me to my final question, which regards the impact of policy, funding, and evaluation frameworks on storytelling projects. In broader peacebuilding terms, storytelling seems to combine an acceptable form of dealing with the past with the new and popular paradigm of "the local turn" in conflict resolution (Mac Ginty and Richmond). But it is also a mechanism that has received increasing funding in the years 2007-2013 through EU's Peace and Reconciliation Programme, Peace III. In this funding program, there was an overwhelming focus on reconciling communities in acknowledging and dealing with the past and one of the deliverables was that "significant groups of the population are able to see and hear a different culture and history of the conflict." At the same time, while there was this funding for dealing with the past, there is also (still) an absence of local government policy for dealing with the past. So, considering that storytelling projects like yours are established with specific objectives tied to their funding, I am alert to this dynamic and its potential power in propelling some accounts to the top while silencing others. So my first question here would be: how did the funding framework and simultaneous lack of policy framework shape and impact the Project? 
My second question would be on evaluating these kinds of accounts-not for accuracy as you mentioned above, but in terms of demonstrating impact. How do you measure how people are moved by their own or others' accounts of conflict?

$J P$ : You rightly draw attention to the emphasis on seeing and hearing a different history of the conflict in Peace III. The fact that dealing with the past was at the heart of Peace III made it possible for projects such as 5 Decades to be developed. This is in contrast to the situation today where, at best, they have to be smuggled in through the back door, but I will return to that in a moment. Our emphasis in 5 Decades was on providing people with the opportunity to see and hear different accounts of the conflict, not to replace their own account but rather to expand their understanding of what happened and to acknowledge that there were other experiences.

Peace III opened up space for projects that wanted to deal with the past however, new legislation has shut that space down. From 2013 onwards, the political failure to implement a strategy for dealing with the past has impeded the much needed debate on how to deal with the past as well as blocked essential practical steps such as supporting victims, funding inquests and the ombudsman, the development of an archive, the Historical Investigations Unit, and the re-integration of former combatants including support for ex-prisoner groups, essentially all the elements of the Stormont House Agreement (2014) which the failure to agree (or even to agree to disagree on occasions) has obstructed. In simple terms, 5 Decades slowed down dramatically with the end of Peace III and has only continued with limited short-term funding. The new EU funding program, Peace IV, is so constrained by current legislation that it is highly unlikely that a project similar in nature could or would be supported by it.

You asked about evaluation, particularly in relation to demonstrating impact. The obvious starting point is the willingness of participants to engage in a project that is explicitly about reconciliation and examining the past. The next step is to hear the comments of participants during and after their engagement in the Project. They tend to report that their understanding of the past has been expanded by hearing the experience of others, both within their own community and in other communities. Then there are the comments on the public material produced by the Project, primarily the exhibitions and the publication. These tend to focus on how the project illustrates the possibility of developing a wider, broader account of the conflict, that it is possible to move beyond the tendency in public discourse to focus on zero-sum accounts, where only one side can be correct. While logically an inclusive account will tend to be more accurate, in reality the public realm is dominated by one-sided, contested accounts. However, creating a practice of 
developing inclusive accounts is not straightforward, and I think a significant impact of the project has been its contribution to demonstrating that this is possible.

I am not sure that changes in individuals are that significant. While it is possible to point to individual participants who would report that they have a more generous view toward the other community as a result of participation in the Project, the wider impact of this is limited. One area participants have drawn attention to is their increased confidence in talking about the conflict to their children and grandchildren, so there is some sort of impact in that area. But, for me, the crucial impact of the Project is demonstrating inclusive ways in which a divisive and difficult past can be presented in a way that allows for difference. That a richer, fuller story that includes as wide a diversity of experience as possible is not only a more accurate account but a stronger foundation to move forward from than zerosum storytelling. I would add one note of caution: richer, diverse stories include the dominant narratives of nationalism and unionism. There is a tendency in Northern Ireland among some involved in community relations work and storytelling to see diversity as an alternative view to the two dominant narratives. This, of course, is an approach that restricts diversity.

To conclude on a more positive note, one of the ways I hope the Project has made an impact is by emphasizing that there is much to be learnt by examining past memories. What at first sight may appear as nostalgia can give us real insight into constructing positive futures. For example, many participants in 5 Decades indeed recall the 1960 os not only as a time of increasing tension but also as a time of growing freedom and possibility or recall particular events during the conflict, such as the Ulster Worker's Council strike in 1974, as events in which communal bonds were strengthened. Storytelling can remind us of what is too often left out of more conventional historical accounts.

SM: From what you are describing, it is clear that the fluid policy context in Northern Ireland on how to deal with the past has serious repercussions on the articulation of different experiences of the past, conflict, and coexistence. At the same time, it seems the policy vacuum allowed for many oral history projects to emerge from the bottom up, which hopefully means that a myriad of voices will be preserved and constitute a reservoir that may challenge dominant narratives emerging over time in an ongoing historical dialogue. Similarly, your observation about surprising solidarities-about people feeling more confident talking about their individual experiences across and between generations, and not just as collective suffering and cultural trauma (Alexander et al.) - is an important consideration for conflict transformation, and a potential tool of historical dialogue. I really appreciate having 
this conversation with you and I will particularly keep the idea of continuously allowing for differences and how processes and products give shape to each other in mind through the next dialogue.

\section{A CONVERSATION ON THE POTENTIALS AND PITFALLS OF BRINGING MEMORY TO WORK IN A MISSION ORGANIZATION}

While religion continues to be an important symbolic marker of difference in Northern Ireland, the 5 Decades project did not engage directly with religion in producing and reproducing communal memories and identities. The following conversation with Henrik Sonne, Programme Director for Church and Dialogue in the Danish organization Danmission, grapples specifically with religion as a driver of conflict and peacebuilding. There is of course a sizable literature on religion and spirituality in peacebuilding (see for example Appleby, Omer, and Little; Lederach), as well as important work on religion as a "chain of memory" (Hervieu-Léger). Here we focus more broadly on memory as a category and catalyst of work in the specific context.

Danmission is a faith-based organization in the tradition of the Evangelical Lutheran Church of Denmark. Historically, Danmission has been active in Asia, Africa, and the Middle East as a mission organization for more than 150 years, and in the last 20 years, Danmission has deliberately aimed at building competences within the field of dialogue in and among religious traditions, alongside a continuation of traditional support of Church partners, and engagement with development activities. Empirically, this conversation is informed by activities in Tanzania, Zanzibar, and Madagascar, where Danmission is involved with different Pan-African organizations like the Program for Christian Muslim Relations (PROCMURA) and All African Conference of Churches (AACC).

\section{On Locating Memory Work in Preventive Dialogue}

SM: This discussion will explore the possibilities and pitfalls of establishing memory work, more firmly on the agenda for development and peacebuilding practitioners. I think we agree that dealing with the past (as history and memory) does not figure prominently in the work of Danmission, although it obviously forms part of the work environment. Most protracted conflicts have a "history" (or indeed, several parallel histories) and a living memory, that is, a set of narrative templates, which conflict parties adhere to and which are being maintained by different custodians, 
practices, and institutions. Can you identify concrete ways in which the history and memory of conflict complicate your work, and to what extent you directly engage with this dynamic?

Henrik Sonne (HS): I hope you will allow me the liberty of not only answering your question but also engaging with the precondition expressed in it: While we don't engage through the terminology of memory studies, Danmission nevertheless engages quite a lot with the past. Insofar as Danmission aims at engaging with religious people and traditions, a lot of attention is devoted to issues like identity, relationships between different religious groups and traditions, and relationship with a (more or less) secular state. In all of these issues, the past and tradition of course loom large.

One of the reasons for this specific attention to the past among religious actors is the fact that the constitutive event is a historical situation, as, for example, the revelations received by Mohammed or the life and death of Jesus of Nazareth. The past is as such an inherent part of religious identity, at least in the mainline expressions of Christianity and Islam, and we have to deal deliberately with the past, whether we engage in capacity-building of church structures, in development engagement, or in conflicts involving religious actors. Especially in relation to conflict, where Danmission has a special focus on "preventative dialogue," the past is so to speak present. Preventative dialogue aims to establish relations in and among religious actors, especially the Christian and Muslim traditions when we think of Africa, and the overall goal is to generate a mutual understanding that invites the communities to solve conflicts in non-violent ways. In this dialogue, the constitutive past of the faith traditions is invoked to legitimize the growing of peaceful attitudes to the "religious other."

You ask how history and memory of conflict complicate the work of Danmission, and let me initially point to the phenomenon of "negative solidarity." This is an expression framed by Dr. Johnson Mbillah, General Advisor of PROCMURA, and he identifies it as "that which propels some Christians and some Muslims to be in solidarity with their co-religionists at all and any cost. It propels them to be in solidarity even when heinous crimes that are religiously and morally reprehensible in their own religious precepts and etiquette are committed." Negative solidarity is one of the places we touch on the question of collective identity and corresponding collective memory. I would be interested to know how memory studies suggests to include collective identity in an understanding of conflicts. The other complication I will point to has to do with so-called intra-religious mechanisms, that is, how Muslims relate to Muslims, and Christians to Christians. These kinds 
of intra-religious relations are important to build a common resilience against polarization following events such as the violence of Boko Haram and Al-Shabaab. Furthermore, investigations in Africa undertaken by AACC, among others, indicate that religious actors incorporate a considerable moral authority in conflict situations, if they can address the situation together, across religious differences. But this possibility of standing together erodes where Christians/Muslims disagree among themselves. Since we talk about intra-religious relations let me address the challenge within the Christian family of faiths in East Africa.

The complication relating to intra-religious relations is a difference in "historicality" (a terminology from Paul Ricoeur), that is, a difference with regard to the orientation in time of the legitimating narrative. On the one hand, there is a rather conservative outlook among mainline churches, with a concern for doctrine and structure, which directs attention toward the past, whereas a growing revival movement has a staunch focus on the present. The focus on the present is more appealing to the youth, where a more settled generation, as ourselves, develops a more conservative outlook, aiming to preserve the achievements. But, the understanding of temporal narratives encountered is not only differentiated along generational lines but also along social lines, as people living in poverty are naturally concerned with ways to secure food for today and tomorrow, and improve living conditions for their children just a little. So, the historicality encountered in intrareligious relations involves generational and social stratifications of narratives, which make it necessary to deal specifically with challenges relating to the different groups.

Having said all these, I would like to pose a question. I have found it rewarding to engage more with memory and memory studies, insofar as it directs attention toward social, cultural, and cognitive backgrounds of conflicts. The focus on narratives, communities, and tradition is common a concern with conflictpreventing work among many religious actors, at least as far as I know. But, is memory studies able to embrace the particularities of religious traditions? The challenge in dealing with religious actors involved in conflict is, among other things, a challenge to avoid essentialization. This is evident in many places across the world and in Africa, too, where the terrible violence of Boko Haram in the West and Al-Shabaab in the East, to mention only a few, generates suspicion towards local expressions of Islam. In other words, does memory studies allow for what I have called "sympathetic engagement," where the particularities are visible and the religious realm is accepted as an integrated part of reality? I'm asking for a method exempting neither Islam nor Christianity, but for an approach without stereotypes, allowing us to focus on the performance, that is, "religious practice," distinguishing good from harmless and harmful attitudes when it comes to tensions and conflict. 


\section{On Dialogue Dynamics between Tradition, Religion, Postcolonialism, and Collective Memory}

SM: Your question points to what is tricky about memory studies. Firstly, in terms of how to distinguish "collective memory" from "tradition," "ritual," and "custom"that is, what kind of a process collective memory is needs to be considered. This is especially interesting in relation to faith and faith institutions (in material and ideational terms), which often "hold custody" of memory, but also in terms of differences between modern and traditional societies. So much of memory studies is perched on the transition from traditional to modern society and the loss of living memory-or as Nora wrote: the transition from milieux de mémoire (environments of memory) to lieux des mémoire (sites of memory). Thinking about memory and memorialization in relation to what we might term more traditional or customary societies forces us to reflect on cultural differences in terms of how present the past is. Different cultural constructs of time, generations, death, and afterlife mean that a generic approach to memory conflicts and transformations will only get us so far (Hopwood). This also means that we are conducting more than one historical dialogue (as we often are), that is, the dialogue framed by different origins of time and authority in religious terms and the narrative of conflict in contemporary terms-what is remembered and historicized about conflictual interactions (Assmann, "Transformations between History and Memory"). Thus, a memory studies approach cannot afford to ignore faith-not as an institutional framework for creating a historical past for communities, or as a private practice for re-embodying such histories-or indeed, breaking away from them. Secondly, you point to the inherent tensions in memory studies in your question about whether conceptualizations of "collective memory" allow for flexibility and reflexivity both in terms of particularities and differences. It has been a problem in the past that memory studies often essentialize collective memories by treating them as bound by established ethnic or national communities, as is mentioned above. In conflicted societies, such "bonding memories" may cause broader "memory rifts" as clans, communities, and collectives remember against each other or conversely cannot remember (in public) or be remembered at all. This leads directly to a third point, which is the question of how to express and navigate not just differences between communities but also within communities, such as differences between generations, social positions, gender and so on. In conflicts that are construed as sectarian, these differences are often glossed over as secondary to the main divisions. However, intra-communal differences, may provide narrative templates for inter-communal solidarities. 
For example, Boko Haram, as a group, understands Nigeria to be a colonial construct, and that to regain its former glory it is necessary to "return" to a form of Islamic governance on the model of historic caliphates. Here, the groups' adherents clearly avail themselves of a historical memory in authenticating and legitimizing a present political project. I would be very interested to ask you to what extent it makes sense to engage with this particular historical interpretation. I imagine anti-imperialist critiques resonate with many people, also those who do not see a caliphate as a solution to the problems it identifies. Do you, as an organization, come across these historical interpretations, and how do they reverberate and resonate in the presence, for the people you work with? Put in other words, and maybe conceived, slightly differently: alongside religious myths of origins, how do people make sense of how they arrived at where they are and where they want to go? What are the important events through which they trace their history and memory?

HS: The past that Danmission engages with in East Africa includes both the latest incident or atrocity and the more distant past. The nature of lived memory and historical memory is such that at times it can be difficult to differentiate between the two. Certainly, religious narratives are increasingly employed in contemporary situations of high social tension, which we have noticed, for example, in our ongoing engagement in Zanzibar. In 2005, the Joint Committee for Religious Leaders for Peace Building in Zanzibar was established as a result of cooperation between the Mufti's Office, the WAKF (administration of Muslim endowments), Kadhi courts, and the Anglican, Catholic, and Lutheran churches in Zanzibar. Danmission was invited to participate by the latter. Since then, Danmission has cooperated with the Mufti's Office to counter violence related to elections specifically, and in more general terms to reduce tensions between religious groups through preventive dialogues. In many of our engagements, a low-level conflict, a seemingly mundane political tension may take on religious overtones, such as the use of religious vocabulary, or the emphasis on religious or ethnic differences. The result is that relations to other faith-traditions can quickly deteriorate. Apoli Kameni describes the most protracted conflicts in Africa as conflicts relating to natural resources, but often such conflicts are not interpreted as power struggles, and are rather disguised as ethnic or more often religious conflicts. If this is the case, we need to consider how religious narratives contribute to protracting conflicts, or, conversely, how religious narratives can help prevent conflicts over resources from becoming protracted. Are there ways that we can engage in dialogue with religious narratives to promote resilient relationships and a resistance to violence? These are questions we in Danmission and our partners try to address together. We know that community memory is related to soil and holy places, and we consequently

Kritika Kultura 33/34 (2019/2020): 719-728

(C) Ateneo de Manila University

<http://journals.ateneo.edu/ojs/kk/> 
seek ways to deal with memory within safe spaces, building relations, providing education and analysis, and trying to identify indicators in the field of interreligious dialogue.

In this, it is essential to understand that layers of memories are not chronologically or even logically ordered. Rather memory is more a dynamic entity (like "temporality" in the work of Heidegger, or mystical "transcendence" in Levinas), allowing even opposites to co-exist, with the implication that conflicts and memories of conflicts cannot be explained in binary terms: invisible/visible, secular/religious, good/evil, modern/traditional. Instead, we need to understand contexts in terms of multipolarity (describing a plurality of power-centers) and pluriformity (expressing one reality in different cultural forms), where opposites do not necessarily exclude each other and where several forms of memory may call upon one another.

For example, several members of a community in East Africa maintain good relations with the family village, often by having a plot of land there, although they live and work in a modern or postmodern urban reality. In this sense, they retain a circle of memory, tied to soil and extended family history, which makes the historic past of the family present amidst the modern life in the city. These same friends often add a layer of memory to this circle, as they engage with fellowships of faith.

Returning to a religious complication you mentioned yourself: I believe it is important to recognize at least two layers of memory related to faith traditions. One is the doctrinal layer, referring to constitutive events (e.g. life and death of Jesus; revelations received by Muhammed), while the other relates to religious practice and experience. The doctrinal aspect is a fixed world view and it is in this regard correct to understand faith traditions as custodians of a "chain of memory" (Hervieu-Léger).

The other element of religious memory relating to faith experience draws on the lived past. This aspect of memory refers to religious practice, and as such it arises from prayers, performance of liturgy, the shape (or absence) of social engagement, and the subjects (or neglect of subjects) in preaching. Of course, there is often a considerable overlap between doctrinal and practice-related memory but they are not necessarily the same, as practice-related memory has a dynamic character and can develop. Recently, we have seen a rise in what we call "pentecostal charismatic" groups and they emphasize the experiential aspect of religion and have a strong focus on contemporary, everyday problems such as sickness and health. As opposed to the more established churches, they do not necessarily support the existing power structures of church and state, but offer alternatives. Some of these actors, while religious, can hardly be understood as custodians of memory, as they 
break away from traditions and the understanding of religion as a chain of memory that should be safeguarded (Urbaniak). Instead, the chain of memory seems to be broken, allowing new memories to spring forth, which in some ways employ a polarizing religious language, as the anthropologist Birgit Meyer has shown, but at the same time offer a loving and including fellowship for people otherwise on the fringes.

Finally, returning to your initial question about historical checkpoints: if one considers the case of Zanzibar and takes a longer perspective, one does find that religious languages sometimes invoke the grand history of country, its being the proud home of the Sultan, which was colonized by the British and German empires, and dissolved in the de-colonizing years of the 1960s. And because the Sultanate of Zanzibar was heavily involved in slave trade, a discourse on slavery can be invoked as it has a significant role in current political discussions in Africa. In Danmission we have had initial discussions on a project exploring some of these questions. It seems there are particular experiences of conflict along former slave trade routes in Tanzania which speak to and relay historical lines of trading, owning, and being slaves. Here, the issue is whether memories of this traumatic past have ramifications for the collective memory in the present and whether subscribing to a tradition as "custodians of the past" or to a more experiential attitude has implications for the way we can have historical dialogues and for how conflicts are solved.

SM: You raise questions about multidirectional meaning-making, master narratives, and the role of religious and other authorities in assembling and maintaining memories. The move from institutional to experiential bases of religion is a particular challenge, especially if the entry points in peacebuilding are through existing institutions and traditional authorities/leaders. With regard to the history and memory of slavery in relation to your emerging ideas of finding new entry points for dialogues, since the 198 os there has been a growing body of work on the legacies of slavery, and in fact UNESCO launched the Slave Route Project in 1994. In official terms, it was meant to "contribute to a better understanding of the causes, forms of operation, stakes and consequences of slavery in the world [...] Highlight the global transformations and cultural interactions that have resulted from this history [and; Contribute to a culture of peace by promoting reflection on cultural pluralism, intercultural dialogue and the construction of new identities and citizenships" (see also, UNESCO $27 \mathrm{C} /$ resolution 3.13). However, there is also evidence that some of these projects have played out in particular ways in East Africa, where the heritage-making of slavery mostly resulted from state-led programs associated with economic growth and poverty reduction with little involvement of the local population (Fouéré and Hughes 545). This lack of 
involvement arguably stems from how the historical experience of slavery has been remembered and silenced and what it means in present-day East Africa (Klein).

Transitional justice reminds us that in any project trying to deal with the past, it is important to consider the motivation behind the project. For example, is it for psychological and therapeutic purposes, that is, a form of catharsis for victims or descendants? Is it for legal and judicial purposes as in rights, retribution, or reparation? Is it for political purposes to delegitimize the past and legitimize the present? Or is it for restorative purposes to construct collective narratives for the future and some form of historical justice? (Teitel). Often these intentions overlap and at any rate can rarely be pursued separately. Increasingly, we also remember as part of what we might call "heritagization" and "historicizing" of the past, in which the concept of heritage goes beyond a materialist, preservationist agenda and points toward peacebuilding and reconciliation. The critical strand in heritage studies (and memory studies) also reminds us that we should be attentive to the multitude of agendas and actors (as you mention yourself with the plurality of civil society actors in East Africa) at the international, national, and local levels, who of course are likely to have widely differing motivations for engaging with the past.

Questions of why and for what purposes the past should be engaged relate to memory work in different contexts, as illustrated in my previous conversation with Johnston Price. That is, considering how people are encouraged to remember or reflect on the past, both as part of existing practices and as part of future projects, directly impacts the ways in which communities relate to one another and the history of violence that divides them. In her work on Sudan, Stephanie Beswick explores how fierce wars, ethnic struggle and expansion, and external slave raids shaped the socio-political and religious culture of the region. In this case, one might ask if the memory of slavery is an entry point into the past in East Africa which could potentially cut across existing divisions to make room for constructive cross-pressures or even reveal surprising solidarities. Also important to consider is whether there exists a dominant narrative (or silence) and how a dialogue on this part of the past would contribute to a sense of origin/community/nation. The kind of project you are thinking about would be able to draw on the extensive work already done on slavery and memory, while also being a case for rethinking your own peacebuilding practices through uses of the past and bringing together multiple bodies of literature and critical approaches in conceptualizing the issues at stake. 


\section{CONCLUSION}

In exploring how the grassroots work explored herein addresses the issue of how to deal with differences between and within groups, I will conclude with a consideration about modes of memory in historical dialogues. There has been much criticism of the idea of cosmopolitan memory (Levy and Sznaider) which refers to a process of "internal globalization" through which global concerns become part of local experiences of an increasing number of people. Criticisms include that it "standardizes" Western memorial modes of how to deal with past tragedies and atrocities (David). But such concerns go beyond the NorthSouth and East-West divides. In both the literature on peacebuilding and in the literature on memory studies, there is a growing concern that we should not always try to transcend differences (Ramsbotham; Aggestam et al.; Bull and Lauge). Often this emanates from ideas of "agonistic pluralism" originally coined by Chantal Mouffe in 1999. Agonistic pluralism was conceived as an alternative to deliberative democracy where "enemies" were transformed into "adversaries" without eliminating antagonism and without glossing over ongoing political, social, and cultural struggle. As such, the prime task of democratic interactions is not to eliminate passions, but to mobilize them towards the promotion of democratic designs (Mouffe 755-756). That is, moving from violent antagonism to non-violent agonism. In dialogues with the past, this means challenging both an antagonistic memory mode where groups are remembering "against" each other and rejecting each other's past, sometimes violently, but it also means complicating cosmopolitan modes of memory in which global discourses of individual human rights and universal norms may cloak ongoing conflict, contestation, and emotional belongings. Instead, an agonistic mode of memory would accept ongoing political conflicts and group identification but aim to challenge this without violence and preferably without entrenching differences. It comes very close to what Johnston Price describes as a "shared but not necessarily agreed past" and correlates with Henrik Sonne Petersen's preventive dialogues work. For this to be possible, we return again to the question of how people are encouraged to remember and here we must reflect not just on existing traditions, discourses, and practices but also on transnational interpellations between these and funding and policy regimes, expertise (in academic, NGO, and local terms), programs, and partners. As such, we would move on to a reflexive mode of memory where we also draw attention to problems and processes of remembering, encourage critical thinking, and facilitate ongoing cultural exchange-that is, recognizing not only the potential in historical dialogues, but also how frameworks for historical dialogues give shape to the past, present, and future. 


\section{Notes}

1. The written dialogue took place from Autumn 2016 to Spring 2017 between Dr. Sara Dybris McQuaid (Aarhus University), Johnston Price (Director of the 5 Decades Project, Forthspring, Belfast) and Henrik Sonne Petersen (Programme Director for Church and Dialogue, Danmission).

2. Academic references informed but were not initially all included in the email dialogue. However, to meet the criteria of academic publication, they have been added to this article, without changing the original flow of the conversation.

3. Healing Through Remembering is an independent initiative made up of a diverse membership with different political perspectives working on a common goal of how to deal with the legacy of the past as it relates to the conflict in and about Northern Ireland (see http://healingthroughremembering.org).

4. These were all different outputs produced by the 5 Decades Project.

5. Another project which focuses on the needs of the individual by creating a space for reflection and recognition of individual experience and supporting individuals to share theirstories.Seehttps://thejunction-ni.org/towards-understanding-healing/.

6. The Belfast Project at Boston College had collected life stories from the rank and file of paramilitary organizations like the IRA and the UVF from 2001 to 2006 for a future establishment of a historical record, but these have been subpoenaed by law enforcements agencies in Northern Ireland since 2011 to be used in current and potential trials. For more on this, see Beth McMurtrie's investigation from $2014 \mathrm{http} / / / \mathrm{www} . c h$ ronicle.com/interactives/belfast. 


\section{Works Cited}

Aggestam, Karin, Fabio Cristiano, and Lisa Strömbom. "Towards Agonistic Peacebuilding? Exploring the Antagonism-agonism Nexus in the Middle East Peace Process." Third World Quarterly, vol. 36, no. 9, 2015, pp. 1736-1753.

Alexander, Jeffrey, Ron Eyerman, Bernard Giesen, Neil J. Smelser, and Piotr Sztompka. Cultural Trauma and Collective Memory. California UP, 2004.

Appleby, R. Scott, Atalia Omer, and David Little. The Oxford Handbook of Religion, Conflict and Peacebuilding. Oxford UP, 2015.

Assmann, Aleida. "Transformations between History and Memory." Social Research, vol. 75, no. 1, 2008, pp. 49-72.

--. “Transnational Memories." European Review, vol. 22, no. 4, 2014, pp. 546-556.

Barsalou, Judy. "Reflecting the Fractured Past: Memorialization, Transitional Justice and the Role of Outsiders." Memorials in Times of Transition, edited by Susanne BuckleyZistel and Stefanie Schafer, Intersentia, 2014, pp. 47-68.

Barsalou, Judy, and Victoria Baxter. "The Urge to Remember." Stabilization and Reconstruction Series, no. 5, Washington, DC, United States Institute of Peace, 2007.

Beiner, Guy. Remembering the Year of the French: Irish Folk History and Social Memory. U of Wisconsin P, 2006.

Bull, Anna Cento, and Hans Lauge. "On Agonistic Memory." Memory Studies, vol. 9, no. 4, 2015, pp. 390-404.

Connerton, Paul. "Seven Types of Forgetting." Memory Studies, vol. 1, no. 1, 2008, pp 59-71.

David, Lea. "Against Standardization of Memory." Human Rights Quarterly, vol. 39, no. 2, 2017, pp. 296-318.

De Cesari, Chiara, and Ann Rigney. "Introduction." Transnational Memory: Circulation, Articulation, Scales, edited by Chiara De Cesari and Ann Rigney, De Gruyter, 2014, pp. 147-168.

Elliott, Sydney, and William D. Flackes. Northern Ireland: A Political Directory 1968-1999. 5th ed., The Blackstaff Press, 1999, pp. 681-687.

Fouéré, Marie-aude, and Lotte Hughes. "Heritage and Memory in East Africa Today: A Review of Recent Developments in Cultural Heritage Research and Memory Studies." Azania, vol. 50, no. 4, 2015, pp. 542-558.

Forthspring Inter Community Group. “Talking about the Troubles” Belfast: Forthspring, 2014.

Galtung, Johan. 60 Speeches on War and Peace. Peace Research Institute Oslo, 1990.

Hamber, Brandon, and Grainne Kelly. "Practice, Power and Inertia: Personal Narrative, Archives and Dealing with the Past in Northern Ireland." Journal of Human Rights Practice, vol. 8, no. 1, 2016, pp. 25-44.

Healing Through Remembering. "Legacy Resources."

http://healingthroughremembering.org/resources/legacy-resources/. Accessed 25 Feb. 2019.

Hervieu-Léger, Danièle. Religion as a Chain of Memory. Polity Press, 2000. 
Hopwood, Julian. "We Can't Be Sure Who Killed Us: Memory and Memorialization in Post-conflict Northern Uganda." The International Center for Transitional Justice, The Justice and Reconciliation Project, Feb. 2011, https://ictj.org/sites/default/files/ICTJJRP_UGA_Memorialization_pb2011.pdf. Accessed 25 Aug. 2017

Human Rights Council. "A/HRC/28/36." Report of the United Nations High Commissioner for Human Rights, 2014. www.ohchr.org/EN/HRBodies/HRC/RegularSessions/ Session28/Pages/ListReports.aspx. Accessed 8 Dec. 2016

The Junction. "Towards Healing and Understanding" https://thejunction-ni.org/towardsunderstanding-healing/. Accessed 25 Feb. 2019.

Kameni, Apoli Bertrand. Minerais Stratégiques. Enjeux Africaines. Presses Universitaires de France, 2013.

Klein, Martin A. "Studying the History of Those Who Would Rather Forget: Oral History and the Experience of Slavery." History in Africa, vol. 16, 1989, pp. 209-217.

Langaas, Arngeir. Unity is Strength. The Joint Committee of Religious Leaders for Peace in Zanzibar, 2005-2013. PhD dissertation. VID Specialized University, 2017.

Lederach, John Paul. The Moral Imagination. Oxford UP, 2005.

Levy, Daniel, and N. Sznaider. "Memory Unbound, The Holocaust and the Formation of Cosmopolitan Memory." European Journal of Social Theory, vol. 5, no. 1, 2002, pp. 87-106.

Mac Ginty, Roger, and Oliver P. Richmond. "The Local Turn in PeaceBuilding: A Critical Agenda for Peace." Third World Quarterly, vol. 34, no. 5, 2013, pp. 763-783.

McDowell, Sarah, and Maire Braniff. Commemoration as Conflict. Palgrave, 2014.

McQuaid, Sara Dybris. "Passive Archives or Storages for Action?" Irish Political Studies, vol. 31, 2016, pp. 63-85.

McQuaid, Sara, and Sarah Gensburger. "Administrations of Memory: Developing a Transnational and Comparative Research Agenda." International Journal of Politics, Culture and Society, 2018. Springer, https://doi.org/10.1007/s10767-018-9300-3

McMurtrie, Beth. "Secrets from Belfast". Chronicle of Higher education. Jan 26. 2014

Mouffe, Chantal. “Deliberative Democracy or Agonistic Pluralism?” Social Research, vol. 66, no. 3, 1999, pp. 745-758.

Nora, Pierre. "Between Memory and History: Les Lieux de Mémoire." Representations, no. 26, Special Issue: Memory and Counter-Memory, 1989, pp. 7-24.

Olick, Jeffrey. "Collective Memory: The Two Cultures." Sociological Theory, vol. 17, no. 3, 1999, pp. 333-348.

The Programme for Christian-Muslim Relations in Africa Newsletter, no. o3, 2013.

Ramsbotham, Oliver. Transforming Violent Conflict. Routledge, 2010.

Ramsbotham, Oliver, Hugh Miall, and Tom Woodhouse. Contemporary Conflict Resolution. Polity Press, 2011.

Rothberg, Michael. "Remembering Back: Cultural Memory, Colonial Legacies and Postcolonial Studies." The Oxford Handbook of Postcolonial Studies, edited by Graham Duggan, Oxford UP, 2013, pp. 259-379.

Special EU Programmes Body. Peace III: EU Programme for Peace and Reconciliation $2007-2013$ Northern Ireland and the Border region of Ireland. Special EU Programmes 
Body Belfast Office, Belfast. https://seupb.eu/sites/default/files/styles/PEACEIV/ PIIIOperationalProgrammeFinal_1.PDF. Accessed 10 Nov. 2015.

Teitel, Ruti. Transitional Justice. Oxford UP, 2000.

Urbaniak, Jakub. "Memories as Religion: What Can the Broken Continuity of Tradition Bring About? - Part Two." HTS Teologiese Studies/Theological Studies, vol. 71, no. 3, 2015. HTS Teologiese Studies/Theological Studies, doi:10.4102/hts.v71i3.2933

--. "Religion as Memory: How Has the Continuity of Tradition Produced Collective Meanings? - Part One." HTS Teologiese Studies/Theological Studies, vol. 71, no. 3, 2015. HTS Teologiese Studies/Theological Studies, doi:10.4102/hts.v71i3.2815 